\title{
Is it Logical Excising All of the Postmenopausal Polyps?
}

\author{
Postmenopozal Poliplerin Hepsini \\ Eksize Etmek Mantıklı Bir Yaklaşım mı?
}

\author{
Ali GEMici, ${ }^{a}$ \\ FIrat TÜLEK, \\ Alper KAHRAMAN, ${ }^{\circ}$ \\ Özgür KAN, ${ }^{a}$ \\ Salih TASSKIN, ${ }^{d}$ \\ Fırat ORTAÇ \\ ${ }^{a}$ Clinic of Obstetrics and Gynecology, \\ Etlik Zübeyde Hanım Training \\ and Research Hospital, \\ Ankara \\ ${ }^{\mathrm{b}}$ Clinic of Obstetrics and Gynecology, \\ Memorial Hospital, \\ İstanbul \\ ${ }^{\circ}$ Clinic of Obstetrics and Gynecology, \\ Mardin KızItepe State Hospital, \\ Mardin \\ dDepartment of Obstetrics and \\ Gynecology, \\ Ankara University Faculty of Medicine, \\ Ankara
}

Geliş Tarihi/Received: 29.11.2016

Kabul Tarihi/Accepted: 03.04.2017

Yazışma Adresi/Correspondence: Ali GEMici

Etlik Zübeyde Hanım Training and

Research Hospital,

Clinic of Obstetrics and Gynecology,

Ankara,

TURKEY/TÜRKIYE

ali_gemici@yahoo.com

This study was presented as a poster in $10^{\text {h }}$ Turkish Gynecology Congress, 30-05 April 2014, Antalya, TURKEY

\begin{abstract}
Objective: The aim of the present study was to address the question whether histologic evaluation is always necessary for women with a suspicion of an endometrial polyp at the postmenopausal period. Material and Methods: Between August 2007 and February 2014 a total of three hundred twenty seven postmenopausal women with a suspicion of endometrial polyp at the trans-vaginal ultrasound with or without a complaint of uterine bleeding were included to the study. Data were collected retrospectively from clinic records. All of the patients treated with hysteroscopy. Pathologic results were the main outcome measure. Results: Two cases of 158 asymptomatic polyps, 16 cases of 169 symptomatic polyps were malign and premalignant. The relative risk of symptomatic polyps is 1,79 . The complication rate was $3,05 \%$ for all cases. At the symptomatic group 2 cases and at the asymptomatic group 8 cases have a complication. The complication rate was increased nearly by 4 times ( $\mathrm{p}=0,027)$. Conclusion: Management strategies for postmenopausal endometrial polyps are controversial. In the light of our data, we suggest symptom-based interpretation for choosing management options. We believe that the management choice of an asymptomatic postmenopausal polyp is expectant instead of excision. Nevertheless, further work needs to be done more broadly to establish expectant management alternatives about the asymptomatic postmenopausal endometrial polyps.
\end{abstract}

Keywords: Polyps; hysteroscopy; menopause

ÖZET Amaç: Postmenopozal dönemde polip şüphesi olan her olguya histolojik örnekleme yapma gerekliliği var mıdır sorusuna cevap bulma amaçlandı. Gereç ve Yöntemler: Araştırmamıza Ağustos 2007-Temmuz 2014 tarihleri arasında postmenopozal endometrial polip ön tanısı ile Ankara Üniversitesi Tıp Fakültesi Kadın Hastalıkları ve Doğum Kliniğinde histeroskopik polip eksizyonu yapılan olgular dahil edildi. Toplamda 327 olgu semptom bazlı, uterin kanaması olanlar (semptomatik) ve olmayanlar (asemptomatik), olarak iki gruba ayrild. Veriler retrospektif olarak elde edildi. Patoloji sonuçları temel ölçüm verisi olarak değerlendirildi. Bulgular: Yüz elli sekiz asemptomatik olgu arasinda 2 olguda, 169 semptomatik olgu arasinda 16 olguda malign ve premalign patolojiler saptandı. Semptomatik poliplerin rölatif riski 1,79 olarak belirlendi. Olguların \%3,05'inde komplikasyon ortaya çıtı. Asemptomatik grupta 2 olguda, semptomatik grupta 8 olguda komplikasyon ortaya çıktı. Semptomatik grupta komplikasyon oranı 4 kat fazla saptandı $(\mathrm{p}=0,027)$. Sonuç: Postmenopozal endometrial poliplerin yönetimi tartışmalıdır. Sonuçlarımız ışığında olguların semptom bazlı değerlendirilmesi ve tedavi yönetiminin bu prensipler çerçevesinde yapılması kanaatindeyiz. Asemptomatik poliplerin eksize edilmesinden ziyade takip edilmesi görüşünde olmakla beraber bu konu ile ilgili yapılacak geniş tabanlı prospektif çalışmalar yönetim stratejilerinin belirlenmesi hususunda daha aydınlatıcı olacaktır.

Anahtar Kelimeler: Polipler; histeroskopi; menopoz

Tr n cases of endometrium cancer one out of 5 patient were asymptomatic at the time of diagnosis. Consequently, asymptomatic cases, especially at the menopausal period, examined detailed in order not to misdiagnose a cancer case. 
Due to the wide use of endovaginal ultrasound at menopause, incidental polyp diagnose is not uncommon and leading invasive management. However, most of the endometrial polyps are benign and affecting up to $13-50 \%$ of women at menopause. ${ }^{1-3}$ Symptomatic polyps have an increased tendency to become malignant in comparison to the asymptomatic polyps. Surgical excision of a symptomatic polyp is recommended; on the other hand, prudent excision of asymptomatic polyps has yet to be established.

The aim of the present study was to address the question whether histologic evaluation is always necessary for women with a suspicion of an endometrial polyp at the postmenopausal period.

\section{MATERIAL AND METHODS}

Between August 2007 and February 2014, women at menopausal state with double endometrial layer lining below $5 \mathrm{~mm}$ with or without abnormal uterine bleeding, with a suspicion of endometrial polyp at ultrasound were included to the study. Data were collected retrospectively from the clinic records. Baseline patient characteristics such as age, age at menopause, years after menopause, body mass index, history of hypertension, and diabetes were recorded by accessing patients clinical history. All of the patients were treated by hysteroscopy. Participants having a history of tamoxifen treatment, cancer and precancerous lesions were excluded from the study. Abnormal uterine bleeding, defined as any bleeding, including spotting in the last 6 months, was searched in the main diagnosis and the clinical history of the patient were used to stratify patients in to 2 groups as asymptomatic and symptomatic group. The pathologic report was main outcome measure and correlated with the endovaginal ultrasound and hysteroscopic findings. The final pathologic report obtained and checked for all cases included. An abnormal outcome was defined by the presence of endometrial cancer or atypical hyperplasia. Atrophic fibro glandular polyps and typical hyperplastic endometrial lining were considered benign outcome. In cases of multiple polyps, the one with the worst pathologic report was considered for this study.
Complication, defined as perforation, bleeding and the infection of the uterus and any condition leading extra hospital stay.

Descriptive, parametric, and nonparametric statistics were applied when appropriate to compare demographic and clinical findings within and between the 2 groups. The diameter of polyps was always treated by nonparametric variables to provide a better description for the few abnormal cases. Both univariate and multivariate logistic regression were performed to analyze all variables, and any possible independent variable significantly associated with an abnormal outcome.

\section{RESULTS}

Total of three hundred twenty seven patients were enrolled to the study. 169 patients were symptomatic and 158 of patients were asymptomatic. Two out of 158 asymptomatic cases (1,26\%) were have malign conditions; one of them was complex endometrial hyperplasia with atypia, other one was low grade endometrial stromal sarcoma arising from the base of the polyp. At the symptomatic group 16 out of 169 cases $(9,4 \%)$ were have a malign conditions; 10 of them were complex endometrial hyperplasia with atypia, 6 of them were endometrial adenocarcinoma. The results of the study are presented at the Figure 1.

The complication rate was 3,05\% for all cases. At the symptomatic group 2 cases $(1,2 \%)$ and at the asymptomatic group 8 cases $(5,06 \%)$ have a complication. Two cases at the asymptomatic group were stayed at hospital one day extra due to the increased pelvic pain. The complication rate is increased nearly by 4 times $(\mathrm{p}=0,027)$ (Figure 1$)$.

\section{DISCUSSION}

In this study we try to answer, whether histologic evaluation is always necessary for women with a suspicion of an endometrial polyp at the postmenopausal period. We found that, two out of 158 asymptomatic patients needed to have additional treatment approach. The ratio of precancerous and cancerous lesion was greater at the symptomatic group $(\mathrm{p}=0.013)$. 


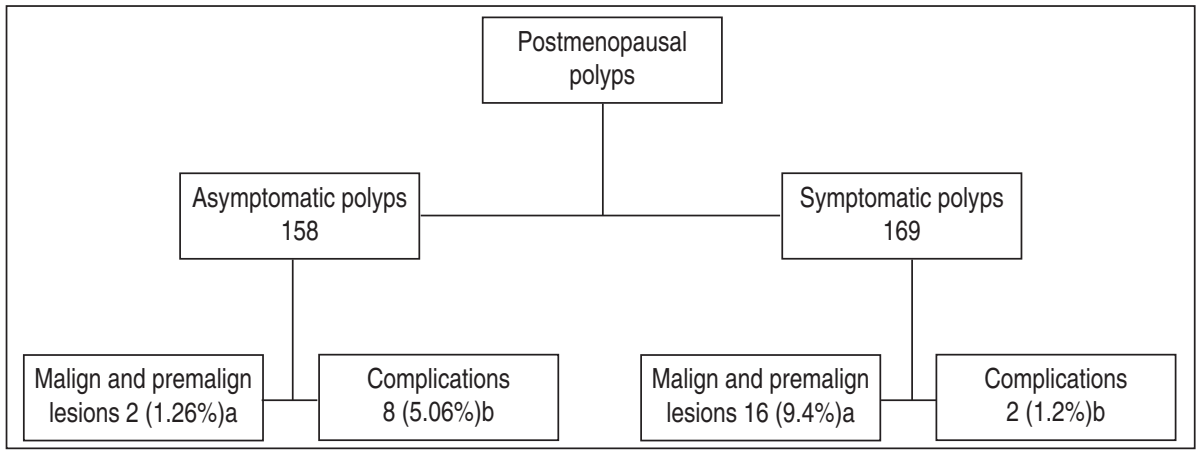

FIGURE 1: Analyses of cases via pathology and complication rates by numbers and percentages. a and b stands for "p" values. a: The difference is statistically significant $p=0,013$; $b$ : The difference is statistically significant $p=0,027$.

The cancer ratio at the asymptomatic group was 6 times lower and the complication rate was 4 times greater than the symptomatic group. In the light of our data, excision of all asymptomatic postmenopausal polyps should be questioned.

The reported cancer percentages of the postmenopausal asymptomatic polyp cases were between $0 \%$ and $4,9 \%$ (Table 1 ). ${ }^{4-10}$ Schmidt et al., reported the highest cancer percentage at the asymptomatic cases. In their survey, hysteroscopy differentiate all of the cancer cases from the benign cases at patients double endometrial layer lining greater than $6 \mathrm{~mm}$, but insufficient to differentiate hyperplasia cases. At that point, there is no disparity with endometrial sampling for diagnosing hyperplasia cases. ${ }^{7}$ The negative predictive value of endovaginal ultrasound is higher. Nevertheless, in cases with double endometrial layer lining greater than $5 \mathrm{~mm}$ endovaginal usltrasound is insufficient to discriminate premalignant or malignant lesions from benign lesions. Additional intervention needed to be done in those cases. Besides, increased endometrial wall thickness can have a contribution for the cancer development much more than the endometrial polyp. In the presented study, we had invastigated patients with double endometrial layer lining below $5 \mathrm{~mm}$ and when symptom based assessment was performed, cancer and pre-cancerous lesions were detected higher at the symptomatic group.

Lee et al. stated that the presence of abnormal bleeding or menopausal status is associated with an increased risk of endometrial neoplasia. ${ }^{11}$ While the endometrium undergoes atrophic changes after the menopause due to estrogenic lack, endometrial thickness is an important finding for the asymptomatic polyp triage. Smilarly in the pre-

TABLE 1: Surveys observing the management of postmenopausal polyps. With pathologic results in symptomatic and asymptomatic patients.

\begin{tabular}{|c|c|c|c|c|c|c|}
\hline Author & Year & $\begin{array}{l}\text { Asympthomatic } \\
\text { (Cancer\&Precancer lesions) }\end{array}$ & $\%$ & $\begin{array}{l}\text { Sympthomatic } \\
\text { (Cancer\&Precancer lesions) }\end{array}$ & $\%$ & complications \\
\hline Gumus et al. ${ }^{4}$ & 2007 & $0 / 77$ & 0 & - & - & Unknown \\
\hline Ferrazi et al. ${ }^{5}$ & 2009 & $1 / 1152$ & $<0.08$ & $46 / 770$ & 6 & $13(1,3 \%)$ \\
\hline Domingues et al. ${ }^{6}$ & 2009 & $1 / 235$ & 0.6 & $28 / 246$ & 11.6 & Unknown \\
\hline Schmidt et al. ${ }^{7}$ & 2009 & $12 / 304$ & 4.9 & - & - & Unknown \\
\hline Golan et al. ${ }^{8}$ & 2010 & $5 / 368$ & 1.3 & $11 / 248$ & 4.43 & Unknown \\
\hline Worley jr et al. ${ }^{9}$ & 2011 & $0 / 65$ & 0 & - & - & Unknown \\
\hline Wethington et al. ${ }^{10}$ & 2011 & $2 / 107$ & 1.8 & $8 / 212$ & 3.77 & Unknown \\
\hline Present study & 2014 & $2 / 158$ & 1.2 & $16 / 169$ & 9.46 & $10(3.05 \%)$ \\
\hline Total & - & $26 / 2466$ & 1.05 & $109 / 1645$ & $\% 6.6$ & \\
\hline
\end{tabular}


sented researh, the results demonstrated that regardless of the endometrial wall thickness any kind of bleeding associated with the endometrial polyp has a high tendency to be a malignant situation on the other hand endometrial polyp with a thin endometrial lining has a high tendency to be benign situation. Expectant management with close followup can be considered in asymptomatic endometrial polyp cases without increased endometrial thickness. Preoperative vaginal ultrasound, hysteroscopic and pathologic findings of the presented study are supporting these findings.

It is obvious that, invasive procedures for managing asymptomatic polyps have been increased; recently. Concerns about misdiagnosing a malignant case can be a reason. Nevertheless, excising all asymptomatic polyps is determining additional costs and medical and psychological side effects with no sound evidence of benefits for patients.

\section{CONCLUSION}

In conclusion, we observe the management strategies of the postmenopausal polyps with endometrial wall lining below $5 \mathrm{~mm}$. Our results demonstrated that asymptomatic polyps have a less tendency to become malignant in patients without endometrial wall abnormality. We believe that expectant management instead of excision can be preferred at asymptomatic polyps. Nevertheless, further work needs to be done more broadly to establish expectant management alternatives about the asymptomatic postmenopausal endometrial polyps.

\section{Conflict of Interest}

Authors declared no conflict of interest or financial support.

\section{Authorship Contributions}

All writers have had equal contribution in all stages of this article.

\section{REFERENCES}

1. Lev-Sagie A, Hamani Y, Imbar T, Hurwitz A, Lavy $Y$. The significance of intrauterine lesions detected by ultrasound in asymptomatic postmenopausal patients. BJOG 2005;112(3):37981.

2. Anastasiadis PG, Koutlaki NG, Skaphida PG, Galazios GC, Tsikouras PN, Liberis VA. Endometrial polyps: prevalence, detection, and malignant potential in women with abnormal uterine bleeding. Eur J Gynaecol Oncol 2000;21(2):180-3.

3. Shushan A, Revel A, Rojansky N. How often are endometrial polyps malignant? Gynecol Obstet Invest 2004;58(4):212-5.

4. Gumus II, Keskin EA, Kilic E, Aker A, Kafali H, Turhan NO. Diagnostic value of hysteroscopy and hysterosonography in endometrial abnormalities in asymptomatic postmanopausal women. Arch Gynecol Obstet 2008;278(3): 241-4.

5. Ferrazzi E, Zupi E, Leone FP, Savelli L, Omodei U, Moscarini M, et al. How often are endometrial polyps malignant in asymptomatic postmenopausal women? A multicenter study. Am J Obstet Gynecol 2009;200(3):235e1-6.

6. Domingues AP, Lopes H, Dias I, De Oliveira CF. Endometrial polyps in postmenopausal women. Acta Obstet Gynecol Scand 2009;88(5):618-20.

7. Schmidt T, Breidenbach M, Nawroth F, Mallmann $P$, Beyer IM, Fleisch MC, et al. Hysteroscopy for asymptomatic postmenopausal women with sonographically thickened endometrium. Maturitas 2009;62(2):176-8.

8. Golan A, Cohen-Sahar B, Keidar R, Condrea A, Ginath S, Sagiv R. Endometrial polyps: symptomatology, menopausal status and malignancy. Gynecol Obstet Invest 2010;70(2): 107-12.

9. Worley MJ Jr, Dean KL, Stephanie NL, Caputo TA, Post RC. The significance of a thickened endometrial echo in asymptomatic postmanopausal patients. Maturitas 2011;68 (2):179-81.

10. Wethington SL, Herzog TJ, Burke WM, Sun X, Lerner JP, Lewin SN, et al. Risk and predictors of malignancy in women with endometrial polyps. Ann Surg Oncol 2011;18(13):381923.

11. Lee SC, Kaunitz AM, Sanchez-Ramos L, Rhatigan RM. The oncogenic potential of endometrial polyps: a systematic review and meta-analysis. Obstet Gynecol 2010;116(5): 1197-205. 